\title{
A NEW SPECIES OF GERVILLIA DEFRANCE (BIVALVIA, BAKEVELLIIDAE) FROM THE APTIAN-ALBIAN TRANSITION OF SERGIPE, BRAZIL
}

\author{
LUIZ HENRIQUE C. DE MELLO, FERNANDA TORELLO DE MELLO \\ \& MARIA HELENA ZUCON \\ Laboratório de Paleontologia, DBI, UFS, Av. Marechal Rondon, s/nº, 49100-000, São Cristóvão, SE, Brazil. \\ torello.mello@uol.com.br,zucon@ufs.br
}

\begin{abstract}
The Aptian-Albian transition bakevelliid bivalves from the Sergipe Basin (northeast Brazil) are examined and described. Gervillia is a cosmopolitan genus of the Jurassic-Cretaceous and is long known from Brazilian beds. Based on a well preserved and abundant material, a new species, G. sergipensis sp.n., is erected for specimens coming from the Cretaceous Riachuelo Formation in Brazil. Examination of this material, allowed the reinterpretation of previous data, providing a more complete characterization and a review of functional morphology and paleoautecology.
\end{abstract}

Key words: Paleontology, Bivalves, Bakevelliidae, Aptian-Albian, Riachuelo Formation, Sergipe Basin.

RESUMO - Os bivalves bakevelídeos da transição Aptiano-Albiano da bacia de Sergipe (nordeste brasileiro) são examinados e descritos. Gervillia é um gênero cosmopolita do intervalo Jurássico-Cretáceo e há muito é conhecido como ocorrendo também em rochas brasileiras. Com base em material bem preservado e abundante, uma nova espécie é descrita, $G$. sergipensis sp. n., para a Formação Riachuelo, Cretáceo do Brasil. O exame deste material permitiu a reinterpretação de dados fornecendo uma caracterização mais completa e uma revisão quanto à morfologia funcional e paleoautoecologia.

Palavras-chave: Paleontologia, bivalves, Bakevelliidae, Aptiano-Albiano, Formação Riachuelo, bacia de Sergipe.

\section{INTRODUCTION}

The elongate bivalve Gervillia Defrance, 1820 is a cosmopolitan genus known from Aptian-Albian transition strata of the Sergipe Basin, Brazil. This paper describes a new species based on well preserved shells and provides information on the paleoecology and life habits of the species and genus. Gervillia is a cosmopolitan genus with well documented occurrences in Jurassic-Cretaceous rocks from Europe (see Muster, 1995 for a revision), Asia (Hayami, 1975; Dhondt, 1987), Africa (Rennie, 1936; Dartevelle \& Freneix, 1957; Silva, 1965; Collignon, 1968), and South America (see Damborenea, 1987 for a revision).

The first record of the genus Gervillia in Brazilian beds was the description of $G$. dissita White, 1887 from the Cretaceous rocks of Sergipe State. Later, White (1887b) transferred this species to the new genus Aguileria White, 1887. Maury (1937), however, revalidate G. dissita and described another Gervillia species: G. regoi. More recently, Hessel \& Filizola (1989) noted that the general external features of those species, such as shape and thickness of the shell, were not compatible with Gervillia and re-assigned them to
Aguileria. Later references report the occurrence of Gervillia from the Turonian beds of Itamaracá Formation in the Pernambuco State (Kegel, 1858; Guimarães, 1964) and from basal layers of Riachuelo Formation in the Cretaceous of Sergipe State (Chagas et al., 2003). Major morphological and ecological data of Brazilian specimens of Gervillia was published by Hessel (2004). The reports of Gervillia specimens in Brazil indicate it had a restricted temporal and spatial distribution.

Although Gervillia shells are common elements of the fossiliferous assemblage recorded from Riachuelo Formation beds (northeast Brazil) in association with well-known ammonites from the Aptian-Albian transition (Zucon, 2005; Zucon et al., 2006), little is know about their internal morphology, systematic placement and paleoecology in Brazil (Hessel, 2004). The overall shell morphology (e.g., anteroposterior elongation, posterior auricule, multivincular opistodetic ligament) is generally compatible with that of Gervillia in the family Bakevelliidae King, 1850. The present study describes Gervillia specimens from northeastern Brazil and presents the taxonomic, systematic, and morphological documentation of the genus. 


\section{MATERIAL AND METHODS}

The material described here consists of 78 specimens preserved as external molds (51 specimens) and original shells ( 27 specimens). They were obtained by preparation of limestone blocks and are housed in the collection of fossil invertebrates of the laboratory of Paleontology of the Universidade Federal de Sergipe (LPUFS ), in Aracaju, Brazil.

Preservation is highly variable and many specimens are laterally deformed (crushed) due to compaction. Complete specimens (articulated or single valves) are rare and most lack the posterior end. In fact, there is only one complete specimen (Figure 3), although comparison with the anterior parts of other fragmental shells indicates that it is one of the largest specimens. Incrustation (e.g., serpulids, oysters) and bioerosion (e.g., dissolution) are also clearly noticeable. Nevertheless, a credible morphological characterization was possible after analyzing the entire collection (Figure 2).

Systematics follows Boyd \& Newell (2002), Cox (1969) with additions by Carter (1990) and Muster (1995). The specimens described by Hessel (2004) were not examined and all comparisons were based on description and figures presented by the author.

The material was collected in the basal layers of the Riachuelo Formation (Figure 1) cropping out at Coqueiro 1 and Taquari 1 localities, Riachuelo City, Sergipe State, Brazil. These layers are dated as Aptian-Albian based on ammonite zonation (Zucon, 2005; Zucon et al., 2006). The ammonite genus Epicheloniceras found in Taquari 1 locality is typical of middle/upper Aptian times. Additionally, Taquari 1 and Coqueiro 1 localities presented the ammonite species Douvilleiceras mammillatum typical of the lower Albian. Both outcrops are described below according to Bengtson (1983) system $(K=$ Cretaceous; $r=$ Riachuelo Formation; $a=$ Angico Member; $m=$ Maruim Member).

Coqueiro 1. Geological map SC.24-Z-B-IV-2 Riachuelo;
Topographic map SC.24-Z-B-IV Aracaju; 1042'48"S, $37^{\circ} 10^{\prime} 51^{\prime \prime} \mathrm{W}$. Cretaceous, Angico Member of the Riachuelo Formation ( $\mathrm{Kra}$ ): inside the Coqueiro Farm, about $100 \mathrm{~m}$ distant from the main road, there is a ca. $8 \mathrm{~m}$ high section of siliciclastic/bioclastic, massive, yellow, fine sandstones or siltstones, with beds sloping $15^{\circ} \mathrm{SE}$. Associated fauna is composed of other bivalves (e.g., trigonids, ostreids), ammonites, and gastropods.

Taquari 1. Geological map SC.24-Z-B-IV-2 Riachuelo; Topographic map SC.24-Z-B-IV Aracaju; 10³8'04"S, $37^{\circ} 01^{\prime} 31^{\prime \prime} \mathrm{W}$. Cretaceous, Maruim Member of the Riachuelo Formation $(\mathrm{Krm})$ : blocks of dolomitic limestones inside the Taquari Farm area. Associated fauna is composed of other bivalves, ammonites, gastropods, corals, and echinoids.

\section{SYSTEMATICS}

\author{
Subclass PTERIOMORPHIA Beurlen, 1944 \\ Order PTERIOIDA Newell, 1965 \\ Superfamily PTERIOIDEA Gray, 1847 \\ Family BAKEVELLIIDAE King, 1850
}

Gervillia Defrance, 1820

Type-species. Gervillia solenoidea Defrance, 1820

Range. Upper Triassic to Upper Cretaceous.

\section{Gervillia (Gervillia) sergipensis $\mathrm{n} . \mathrm{sp}$.}

(Figures 2-5)

Diagnosis. Posteriorly elongated, narrow, inequilateral; anteriorly biconvex and posteriorly flattened shells; equivalve or slightly inequivalve; ensiform with dorsal and ventral margins obviously curved; scarcely oblique; terminal umbones; anterior wing absent; posterior wing about $1 / 3$ shell length; anteroventral byssal gape evident;

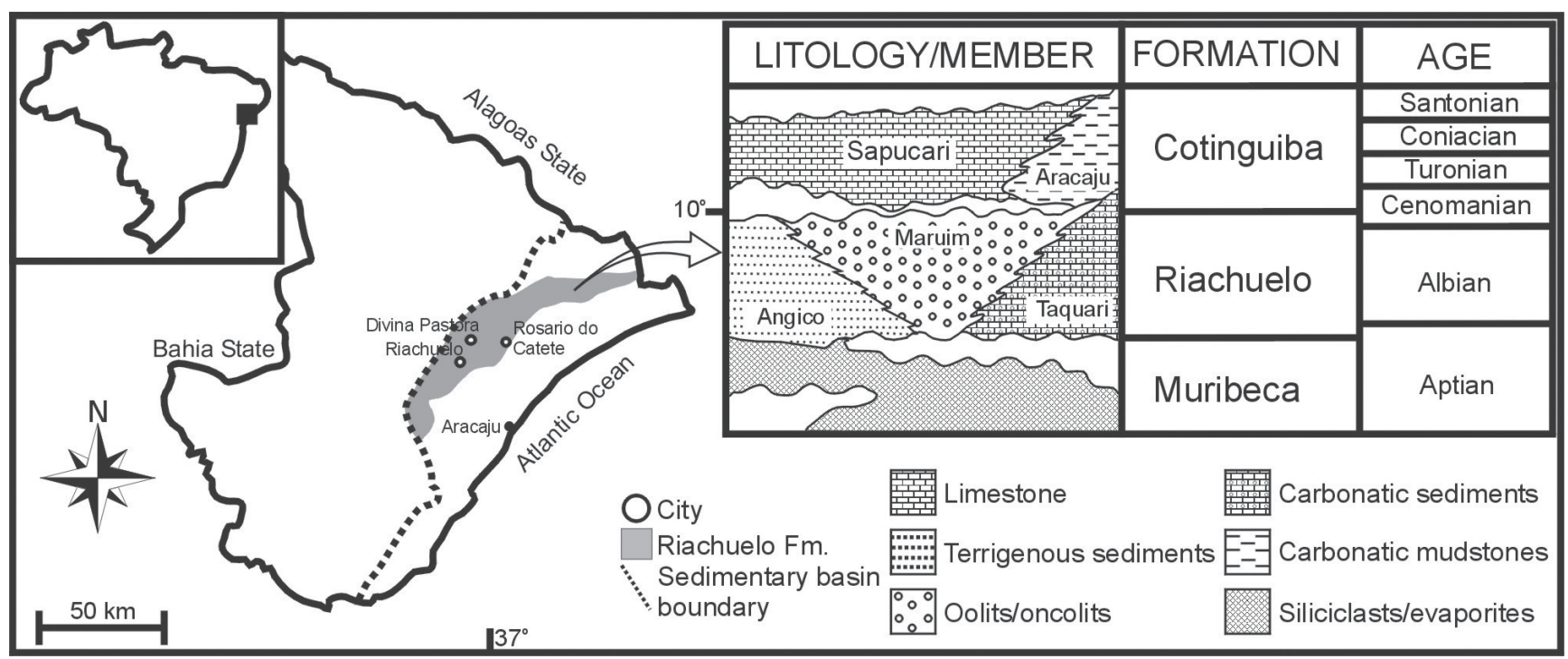

Figure 1. Geographic position of Riachuelo Formation and its stratigraphic relations to other marine unities of Sergipe Basin (Sergipe State, Brazil). 


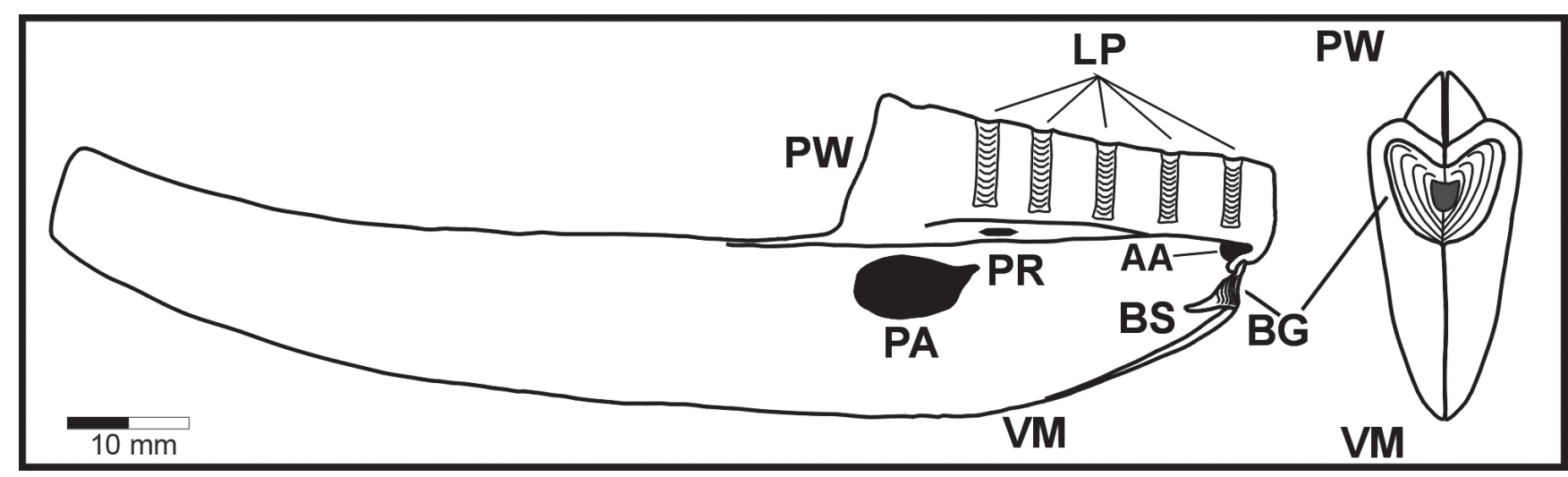

Figure 2. Schematic representation of the morphological features of Gervillia (Gervillia) sergipensis, n. sp. Abbreviations: AA, anterior adductor muscle scar; BG, byssal gap; BS, byssal sinus; LP, ligamental pits; PA, posterior adductor muscle scar; PR, posterior retractor muscle scar; PW, posterior wing; VM, ventral margin.

unornamented except for sparse growth lines; anisomyarian with anterior adductor very reduced; triangular area of opisthodetic ligament, with 5 ligament pits; hinge line with anterior and posterior teeth and crenulations.

Holotype. LPUFS 2686, measuring $130 \mathrm{~mm}$ in length; and 21 mm high.

Paratypes. LPUFS 1934-1984, LPUFS 2341-2364, LPUFS 26872688.

Etymology. Species name, sergipensis, refers to Sergipe State, where the specimens were collected.

Distribution. Riachuelo Formation; Middle Cretaceous (Aptian-Albian transition); Coqueiro 1 and Taquari 1 localities (Chagas et al., 2003 and present study), Mangueira 1 and Espírito Santo 11 localities (Hessel, 2004). All localities are in the area of Riachuelo, Divina Pastora, and Rosário do Catete cities, Sergipe State, Brazil (Figure 1).

\section{DESCRIPTION}

Shell shape. Typically longer than high (Figures 2, 3), with adult shell maximum length of $130 \mathrm{~mm}$ in our material. Ventral and dorsal margins of the body chamber have almost the same curvature. The ventral margin curves and joins the highly incurved anterior margin at the anterior region of the shell and posteriorly the dorsal margin has a sharp and abrupt turn to join the posterior wing margin. Umbones terminal, prosogyral and discrete. Biometric indexes are not presented, because lateral crushing has affected most specimens. Less deformed articulated shells show a biconvex, equivalve (maybe slightly inequivalve) condition for the species (Figures 2, 4B). Biconvexity is particularly evident for the anterior region of the shell since the middleposterior regions are almost completely flat, with small mantle cavity (Figure 3 ). A wide gape high on the anterodorsal margin is indicative of the position of the byssus (Figures 4,5 ). Shell externally smooth or with thin discrete growth lines (Figures 3, 4).

A shallow groove ventrally delimits the well-developed posterior wing from the body chamber of the valve (Figure
3). The posterior wing is triangular in outline and has a straight ventral margin groove sloping $11^{\circ}$ to $15^{\circ}$ relative to the dorsal margin of the valve. The posterior margin of this wing is nearly straight or slightly curved. Growth lines of the posterior margin of the wing are well marked.

Ligament area. the ligament area is triangular in outline with an apex near the beak. Five ligament pits are clearly developed (Figure 3). Their width varies from 2 to $4 \mathrm{~mm}$ and are separated by areas ranging from 2 to $5 \mathrm{~mm}$. Those features are characteristic of a multivincular opisthodetic ligament.

Cardinal area. Specimens with preserved shell are mostly articulated with both valves present, although the hinge is often deformed by compaction. As a result, the hinge may appear folded (Figure 5) and its features distorted. Nevertheless, crenulations are still recognizable on the hinge surface between the anterior and posterior teeth (Figure 5A). The left valve shows two anterior transversal teeth pointing in a postero-ventral direction and at least one elongate posterior tooth (Figure 5B). The opposite valve has a single anterior transversal tooth, at least one elongate posterior tooth and a well marked socket (Figure 5A). The cardinal area is narrow and extends from the anterior end (beak) to the middle of the posterior wing (Figure 5), being intermediate between those of Gervillia metzertensis and G. solenoidea, as figured by Muster (1995). A single long tooth and socket is suggested for the cardinal margin almost on the middle length of the posterior wing (Figures 2,5).

Muscle scars. Specimens with preserved shell show an oval posterior adductor muscle scar under the posterior wing (Figures 2, 5). The anterodorsal part of such scar is elongated as to accommodate the posterior retractor muscle (Figures 2, 5). An oval anterior adductor muscle scar is present in the umbonal region (Figures 2, 5) being characteristically smaller than the posterior one (anisomyarian condition). A triangular scar in front of the byssal gape is evident on one left valve, possibly indicating the placement of a byssal sinus (Figures 2, 5). No evidence of palial line was observed. 


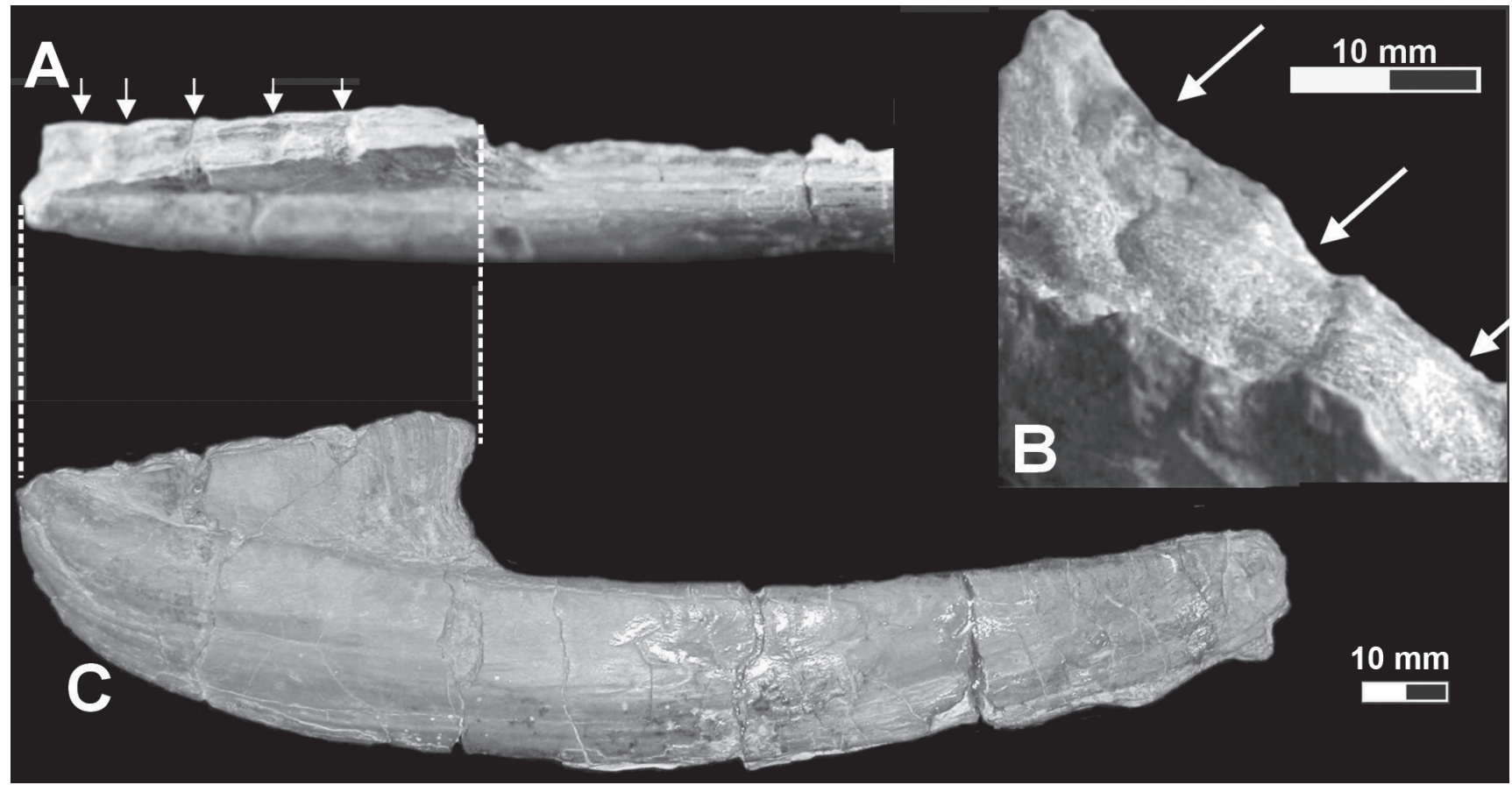

Figure 3. Gervillia (Gervillia) sergipensis n. sp.: A, dorsal view of an articulated specimen, LPUFS 2686 (holotype) showing well marked ligamental pits; B, LPUFS 2688, single right valve, detail of ligamental pits; C, LPUFS 2686, lateral view of the left valve of an articulate complete specimen, showing typical ensiform shell shape and pronounced posterior wing.

\section{DISCUSSION}

\section{Morphological features}

Two subgenera are referred to Gervillia (Moore, 1969; Damborenea, 1987). The subgenus G. (Gervillia) differs from G. (Cultriopsis) in having transverse crenulations along the hinge margin, in addition to elongate transverse teeth. All specimens described in the present paper share the same morphological features with G. (Gervillia), including crenulations and transverse teeth, giving support to their attribution to that subgenus. The position of G. sergipensis new species in the subgenus G. (Gervillia) is supported by the hinge features: crenulations and transverse teeth. All species mentioned and figured by Muster (1995), included in Gervillia (Gervillia) and G. (Cultriopsis), differ from $G$. sergipensis new species, in which the curvature of dorsal

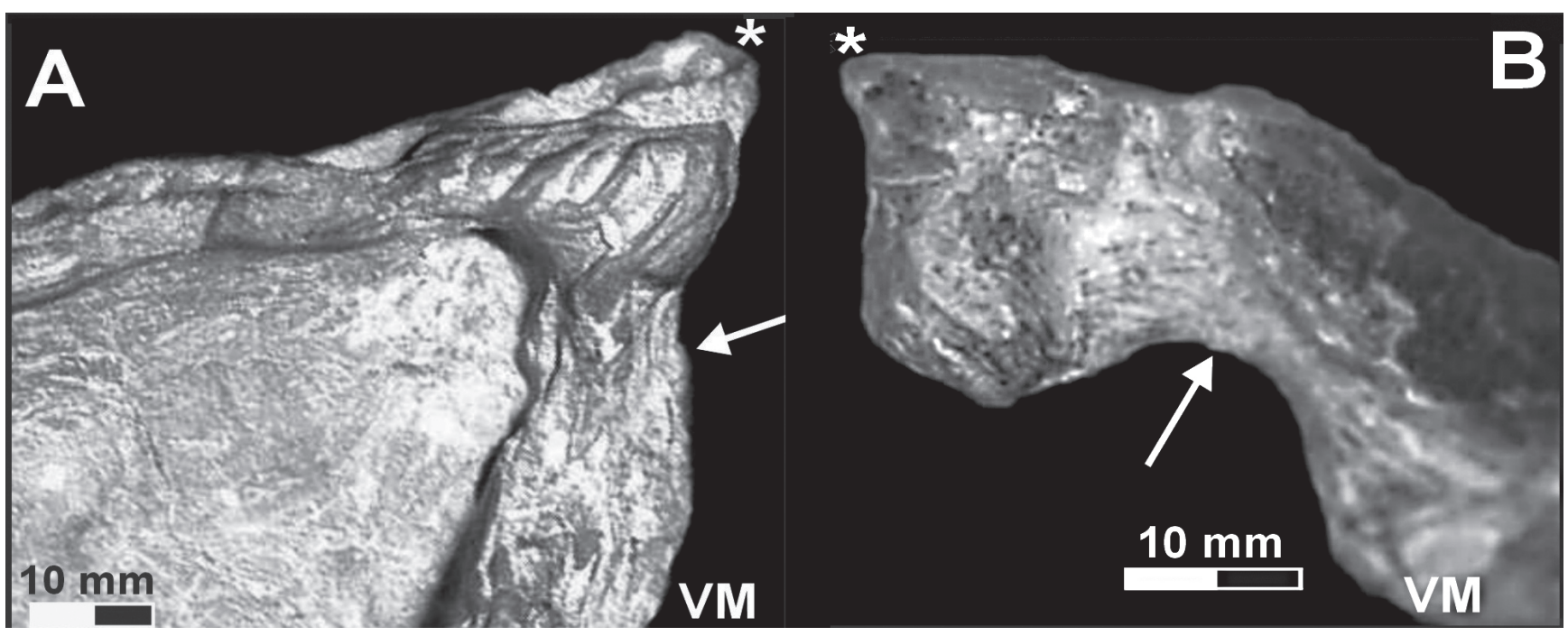

Figure 4. Gervillia (Gervillia) sergipensis, new species, left valve of the specimen LPUFS 2688. A, inner surface of the anterior part of the valve; and $\mathbf{B}$, partial view of the outer surface of the anterior part of the valve. Both (A-B) showing the ventral margin (VM) near the umbones (asterisk) and byssal gap position (arrow). 


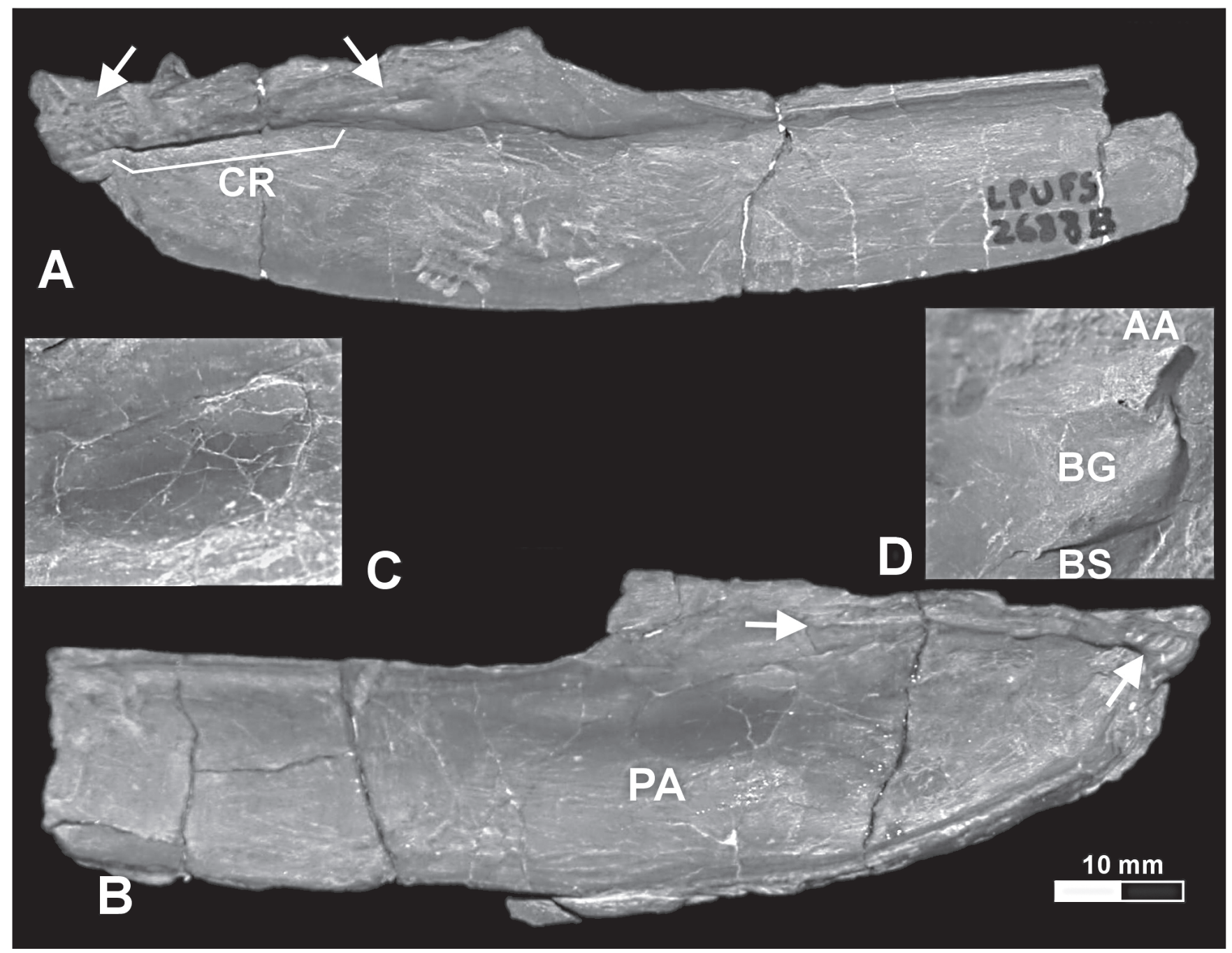

Figure 5. Gervillia (Gervillia) sergipensis n. sp., LPUFS 2688. A, right valve; B, left valve showing internal morphological features; C detail of the posterior adductor muscle scars; D, anterior adductor near umbones hinge line with crenulation area and teeth, and byssal gap with byssal sinus. Arrows points to anterior and posterior teeth. Posterior wing only partially preserved. Abbreviations: AA, anterior adductor muscle scar; BG, byssal gap; BS, byssal sinus; CR, crenulation area; PA, posterior adductor muscle scar.

and ventral margins is more pronounced than the straight outlines of other species (e.g., G. (Gervillia) solenoidea Muster, 1995, G. (Gervillia) glaciana (French, 1902), G. (Cultriopsis) northamptonensis Cox, 1946). On the other hand, the posterior wing is well marked and more developed, externally resembling that of $G$. (Cultriopsis) angusta (Müster, 1826 in Goldfuss, 1826; see also Muster, 1995:81). The cardinal features (e.g., outline, thickness) of Gervillia sergipensis n. sp., seems an intermediate between G. (Gervillia) metzertensis (Joly, 1907) and G. (Gervillia) solenoidea (Muster, 1995). Such unique set of characters supports the description of the new species Gervillia (Gervillia) sergipensis.

However, no other species of Gervillia has the combination of morphological features of shell shape, posterior wing, and hinge line that occurs in G. sergipensis. This is the first time that complete hinge morphology is described for Brazilian specimens.

Gervillia (Gervillia) solenoidea Muster, 1995 is a common element of Aptian and Maastrichtian rocks from Europe, Africa, India, and Japan. Recently, Hessel (2004) identified Brazilian specimens as G. (Gervillia) solenoidea based on general features of shell shape, posterior wing, ligament area and byssal aperture. However, those features are shared by many species and are not distinctive at the species level. No hinge character was described by Hessel (2004) to compare Brazilian specimens with G. (Gervillia) and G. (Cultriopsis). Besides, Hessel (2004) described the ligamental area with four pits (as in G. solenoidea) and posterior wing as a small, sub-triangular, posterior structure. Studies on materials from the same localities show that specimens possess a well developed triangular wing and five well marked pits on the ligamental area. However, the shape of posterior wing can be modified by taphonomic agents and such artifact has to be evaluated before morphological comparisons. In addition, in multivincular ligaments the number of pit increases during ontogeny, but this feature has been largely used both in 
descriptions and comparisons of taxa, including Gervillia species. In this case, the comparison of specimens in the same ontogenetic stage is worthy. As mentioned above, Hessel (2004) used the number of pits to consider the Brazilian specimens as G. (Gervillia) solenoidea.

The differences pointed above suggest that there are two distinct taxa. Comparison with figure 5 of Hessel (2004:74) shows clear similarities of those specimens with the material analyzed herein, such as the shape of the shell and of the posterior wing. However, some of Hessel's specimens need more preparation to show morphological features, since important structures (e.g., posterior wing, ligamental area) remain partially obscured by sediment. Based on this comparison, the specimens under analysis seem to belong to the same species as those illustrated by Hessel (2004). The difference in number of pits between the specimens examined by Hessel (2004) and those examined in the present paper ( 5 pits) is probably because they belong to distinct ontogenetic stages. Therefore, is probable that the specimens identified as G. solenoidea by Hessel (2004) belong to G. sergipensis n. sp., described herein. However, a more definitive identification is premature until this material be examined.

\section{Paleoautecological comments}

Paleoecological interpretation is not the main goal of this study, but the unusual morphology of Gervillia deserves some discussion on its mode of life. According to Damborenea (1987:133), no recent bivalves can be compared in functional morphology to Gervillia (Cultriopsis), a byssaly attached, epifaunal, non-siphonate form, whilst recent ensiform species are all siphonate, burrowing forms. Aberhan \& Muster (1997) expressed similar opinion concerning all bakevelliids.

An epibyssate, pendant mode of life of Gervillia seems to be a general consensus, and from an evolutionary point of view it would have been originated later than the endobyssate forms (Aberhan \& Muster, 1997). Considering the byssate condition of Gervillia and morphologically similar forms, some authors suggested possible surfaces for attachment to be rocks and corals ("corallophilous condition” of Dietrich, 1910:235; Yamani \& Schairer, 1975), floating plants or wood (Sellwood, 1978), and live ammonites ("pseudoplanktic", Seilacher, 1982). Hessel (2004) attributed a pendant mode of life to G. (Gervillia) solenoidea, probably hanging free from macroscopic algae. This deserves further consideration: (i) only microfossils indicate the presence of macroscopic algae in the localities where the bivalves were recorded (Bandeira, 1978; Petri, 1987); (ii) no information was given about the type of algae or dimensions, except for two graphic representations (Hessel, 2004:71-72); (iii) no taphonomic data was used to discuss mode of life or possible attachment surface; (iv) the author assumed a monomyarian condition for Gervillia as well as an epifaunal habit derived from it (Hessel, 2004:72), but this species is anisomyarian; and (v) the author assumed a thin shell for Gervillia (Hessel, 2004:72-73), but that is not correct. A more complete paleoecological analysis based on the specimens analyzed herein is in course but the present study suggests that $G$.
(Gervillia) sergipensis n. sp. had a semi-infaunal life habit. Gervillia was a cosmopolitan genus, living in tropical as well as temperate seas (Dhondt, 1987), and lived in environmental conditions ranging from high energy regions of the inner shelf (Kauffman, 1967) to shallow sea bottoms with weak currents (Yamani \& Schairer, 1975). Based on associated fauna and sedimentological data, Hessel (2004) presented information indicating a marine, high-energy environment with well-oxygenated water conditions.

\section{CONCLUDING REMARKS}

As a cosmopolitan genus, the occurrence of Gervillia in the Brazilian Sergipe Basin, when combined with data from the Congo in Africa (Dartevelle \& Freneix, 1957), provides an opportunity to study the dispersion and behavior of the group in this part of Gondwanaland after the opening of the South Atlantic basin. Also, its functional morphology can be well investigated based on common and well preserved material, giving support for discussion of the genus as a whole.

\section{ACKNOWLEDGMENTS}

The authors are grateful to two anonymous referees for their criticism and suggestions. This paper was a contribution to the XIX Brazilian Paleontological Congress and VI Latin American Paleontological Congress, held in August, 2005, in Aracaju (SE, Brazil).

\section{REFERENCES}

Aberhan, M. \& Muster, H. 1997. Palaeobiology of Early Jurassic bakevelliid bivalves from Western Canada. Palaeontology, 40(3):799-815.

Bandeira Jr., A.N. 1978. Sedimentologia e microfácies calcárias das formações Riachuelo e Cotinguiba da bacia de Sergipe/Alagoas. Boletim Técnico da Petrobrás, 21(1):17-69.

Bengtson, P. 1983. The Cenomanian-Coniacian of the Sergipe Basin, Brazil. Fossils \& Strata, 12:1-78.

Boyd, D.W. \& Newell, D.N. 2002. A unique Pterioid bivalve from the Early Triassic of Utah. American Museum Novitates, 3375:1-9.

Carter, J.G. 1990. Evolutionary significance of shell microstructure in the Palaeotaxodonta, Pteriomorphia and Isofilibranchia (Bivalvia: Mollusca). In: J.G. Carter (ed.) Skeletal biomineralization: patterns, processes and evolutionary trends. Van Nostrand, p. 135-296.

Chagas, R.R.D.; Zucon, M.H. \& Teodosio, C. 2003. Bivalves da família Bakevelliidae King, 1850, Formação Riachuelo, Sergipe, Brasil. In: CONGRESSO BRASILEIRO DE PALEONTOLOGIA, 18, 2003. Boletim de Resumos. Brasília, SBP, p. 102.

Collignon, M. 1968. Le Crétacé Supérieur da Madagascar. Memoir of the Geological Society of India, 2:320-334.

Cox, L.R. 1946. Undescribed lamellibranch species from the English Inferior Oolite. Proceedings from the Malacological Society of London, 27(1):22-32.

Cox, L.R. 1969. Family Bakevelliidae King, 1850. In: R.C. Moore (ed.) Treatise on Invertebrate Paleontology, Part N(1), Boulder 
(ed.) Treatise on Invertebrate Paleontology, Part N(1), Boulder $\&$ Lawrence, Geological Society of America \& University of Kansas Press, p. N306-310.

Damborenea, S.D. 1987. Early Jurassic Bivalvia of Argentina. Part 2: Superfamilies Pteriacea, Buchiacea and part of Pectinacea. Palaeontographica A, 199(4-6):113-216.

Dartevelle, E. \& Freneix, S. 1957. Mollusques fossils du Crétacé de la còte occidentale d'Africa, du Cameroun à l'Angola. 2. Lamellibranches. Annales du Museé Royale do Congo Belge, Sciences Géologiques, 20:1-271.

Defrance, M.J.L. 1820. Gervillie, Gervillia. Dictionaire des Sciences Naturelles, 18:502-503

Dhondt, A.V. 1987. Bivalves from the Hochmoos Formation (Gosau Group, Oberösterreich, Austria). Annalen des Naturhistorischen Museum zu Wien, 88(A):41-101.

Dietrich, W.O. 1910. Ensigervilleia, eine neue Gervilliengruppe aus dem oberen weissen Jura von Schwaben. Centralblatt für Mineralogie, Geologie und Paläontologie, 8:235-242.

French, F. 1902. Über Gervilleia. Centralblatt für Mineralogie, Geologie und Paläontologie, 20:609-620.

Goldfuss, G.A. 1826-1844. Petrefacta Germaniai tam ea, quae in museo universitatis regiae Borussicae Fridericiae Wilhelmiae Rhenanae servantur quam alia quaecunque in museis Hoeninghusino Muensteriano aliisque extant, iconibus et descriptonibus illustrata. p. 122.

Guimarães, D. 1964. Geologia do Brasil. Rio de Janeiro, Departamento Nacional da Produção Mineral, 674 p.

Hayami, I. 1975. A systematic survey of the Mesozoic Bivalvia from Japan. Bulletin of the University Museum of the University of Tokyo, 10:1-249.

Hessel, M.H. 2004. Gervillia (Gervillia) solenoidea Defrance, 1820 (Bivalvia, Bakevelliidae) do Neo-Aptiano de Sergipe, Brasil. Revista Brasileira de Paleontologia, 7(1):67-76.

Hessel, M.H. \& Filizola Jr, N.P. 1989. Algumas espécies de Aguileria (Bivalvia) do Albiano inferior de Sergipe. In: CONGRESSO BRASILEIRO DE PALEONTOLOGIA, 11, Anais, Curitiba, SBG, 1:301-312.

Joly, H. 1907. Les fossiles du Jurassique de la Belgique avec description stratigrafique de chaque Étage. Primière Partie: Infra-Lias. Extrait des Mémoires du Musée Royal d'Histoire Naturelle de Belgique, 5:156S.

Kauffman, E.G. 1967. Coloradoan macroinvertebrate assemblages, Central Western Interior, United States. In: E.G. Kauffman \& H.C. Kent (eds.) Paleoenvironments of the Cretaceous Seaway: A Symposium, The University of Texas, p. 67-143.

Kegel, W. 1858. Um novo membro fossilífero da Formção Itamaracá (Cretáceo Superior), Pernambuco. Anais da Academia Brasilei- ra de Ciências, 29(3):373-375.

King, W. 1850. A monograph of the Permian fossils of England. Monograph of the Palaeontographical Society, 37:1-258.

Maury, C.J. 1937. O Cretáceo de Sergipe. Monografia do Serviço Geológico e Mineralógico do Brasil, 11:1-283.

Moore, R.C. 1969. Treatise on Invertebrate Paleontology, Part N, Mollusca 6, Bivalvia. New York, Geological Society of America, University of Kansas Press, 3v.

Muster, H. 1995. Taxonomie und Palaeobiogeographie der Bakevellidae (Bivalvia). Beringeria, 14:3-161.

Newe1l, N.D. \& Boyd, D.W. 1970. Oyster-like Permian Bivalvia. Bulletin of the American Museum of Natural History, 143:221-281.

Petri, S. 1987. Cretaceous paleogeographic maps of Brazil. Palaeogeography, Palaeoclimatology, Palaeoecology, 59:117168.

Rennie, J.V.L. 1936. Lower Cretaceous Lamellibranchia from Northern Zululand. Annals of the South African Museum, 31:277-391.

Seilacher, A. 1982. Ammonite shells as habitats in the Posidonia Shales of Holzmaden: floats or benthic islands? Neues Jahrbuch für Geologie und Paläontologie, Monatshefte, 1982:98-114.

Sellwood, B.W. 1978. Jurassic. In: W.S. McKerrow (ed.) The ecology of fossils, The MIT Press, p. 204-279.

Silva, G.H. 1965. Contribuição para um catálogo de lamelibrânquios fósseis do Cretáceo de Moçambique. Revista dos Estudos Gerais da Universidade de Moçambique, 2:1-42. (Série 2).

White, C.A. 1887a. Contribuições à Paleontologia do Brasil. Archivos do Museu Nacional do Rio de Janeiro, 7:1-273.

White, C.A. 1887b. On new generic forms of Cretaceous Mollusca and their relation to other forms. Proceedings of the Academy of Natural Sciences of Philadelphia, 39:32-37.

Yamani, S.A. \& Schairer, G. 1975. Bivalvia aus dem Dolomit von Grossmehring bei Ingolstadt (Untertithon, Südliche Frankenalb, Bayern). Mitteilungen der Bayer Staatss Amlung Fur Paläontologie und Historie Geologie, 15:19-27.

Zucon, M.H. 2005. Amonóides da transição Aptiano-Albiano da bacia de Sergipe, Brasil. Programa de Pós-graduação em Geologia, Universidade Federal da Bahia, PhD. Dissertation, 165 p.

Zucon, M.H.; Bengtson, P. \& Kakabadze, M.V. 2006. The initial opening of the South Atlantic Ocean as evidenced by ammonites: a biogeographic assessment of the Aptian-early Albian faunas of northeastern Brazil and Colombia. In: CONGRESSO BRASILEIRO DE GEOLOGIA, 43, 2006. Anais, Aracaju, SBG, p. 141.

Received in October, 2005; accepted in January, 2007. 